\title{
Job Search Strategies and Labour Market Outcomes of Young Recent Migrants from Central \& Eastern Europe in EU15 Member States
}

\author{
Leschke, Janine; Weiss, Silvana
}

Document Version

Final published version

Publication date:

2017

\section{License}

CC BY-NC-ND

Citation for published version (APA):

Leschke, J., \& Weiss, S. (2017). Job Search Strategies and Labour Market Outcomes of Young Recent Migrants from Central \& Eastern Europe in EU15 Member States. SSRN: Social Science Research Network.

Link to publication in CBS Research Portal

\section{General rights}

Copyright and moral rights for the publications made accessible in the public portal are retained by the authors and/or other copyright owners and it is a condition of accessing publications that users recognise and abide by the legal requirements associated with these rights.

Take down policy

If you believe that this document breaches copyright please contact us (research.lib@cbs.dk) providing details, and we will remove access to the work immediately and investigate your claim. 
Janine Leschke, Department of Business and Politics, Copenhagen Business School Silvana Weiss, School of Business, Economics and Social Sciences, Department of Human Resource Management, University of Graz

\title{
Job search strategies and labour market outcomes of young recent migrants from Central \& Eastern Europe in EU15 member states ${ }^{1}$
}

\begin{abstract}
This paper examines the use of social networks and its impact on the qualitative labour market integration of young recent EU migrants from Central and Eastern European member states to EU15 countries as well as Switzerland and Norway. The literature points to both positive and negative impacts of social networks on migrant workers' outcomes. Social networks can facilitate access to employers and information on labour regulation and rights and thereby improve the quantitative and qualitative labour market outcomes of migrant workers. On the other hand, social networks can also contribute to locking migrant workers into sectors and occupations with high shares of migrant workers, so-called niche employment. The latter can lead to suboptimal working conditions including a mismatch of skills and occupation (overqualification) and lower wages. The impact might be particularly negative for recent migrants from Central and Eastern Europe as previous research on EU cross border labour mobility has shown that they are comparatively high qualified and young. The latter might put them at a double disadvantage given that youth have particular problems in entering (quality) employment as they lack work experience which they could use to signal to employers directly and might therefor have to rely more on social networks of established migrant communities.

In contrast to the majority of current research on migrant outcomes and social networks which is based on qualitative research this paper makes use of the 2014 special module on migrants and their descendants of the European Labour Force Survey (EU-LFS). The advantage of the special module is that it includes a subjective measure on over-qualification, one variable of our main interest. Given the existence of migrant employment niches, the standard measures on overqualification are problematic in that they are usually based on occupational information. Importantly, the special module also contains information on how they found their current job including the use of social networks (relatives, friends or acquaintances), another variable of our main interest. Furthermore, beyond the standard demographics and employment characteristics the data also includes information on language competences and other hurdles preventing a person to have a job corresponding with their qualifications including a lack of recognition of qualifications obtained abroad and discrimination by origin, religion or social background. These are factors are likely to be important regarding the impact of social network support in finding employment on the respective qualitative employment outcomes.
\end{abstract}

\footnotetext{
${ }^{1}$ This research acknowledges the support of the H2020 RIA research project ENLIGHTEN - European Legitimacy in Governing through Hard Times: the role of European Networks. European Commission Project Number: 649456
} 
Due to data restrictions we have to compile all the post-2004 accession country migrants into one group (EU13). We do however control for different welfare regimes on the country of destination side given that quantitative and qualitative labour market integration differs substantively across welfare regimes. This is due to variation in the economic situation, labour regulation and institutional settings and language and cultural proximity among others which in turn might impact on the importance and role of social networks in labour market outcomes.

Our analysis shows that in all European country clusters recent NMS13 migrants more often found their current job through social networks than nationals did. At the same time our findings indicate that when recent NMS13 migrants found their jobs through social networks it is more likely that they are over-qualified for the position and that they fall in a lower earnings class as compared to recent migrants who used other job search methods. In particular, young recent migrants are affected rather often by over-qualification and most of them have rather low earnings. Thus using established social networks for job search might go hand in hand with suboptimal qualitative employment outcomes. Immigrant occupational and sectoral segmentation might partially explain this outcome. However, the results differ between different welfare regimes and across individual and job characteristics of the NMS13 migrants.

\section{Introduction}

This paper sets out to analyse how the use of social networks as main job search method impacts on the qualitative labour market integration of young recent EU migrants from Central and Eastern European (CEE) member states to EU15 countries and Switzerland and Norway. The literature points to both positive and negative impacts of social networks on migrant workers' outcomes. Social networks can facilitate information about available jobs and direct access to employers and thereby increase the quantitative employment opportunities of migrant workers. Unfortunately, as the question on social network use is geared to the current job we cannot test the impact of social networks on access to employment with our data but rather look at the qualitative employment dimension. With regard to the latter, first-hand information from social networks on labour regulation and rights in the particular destination country can potentially improve the working conditions of migrant workers. On the other hand, social networks can also contribute to locking migrant workers into sectors and occupations with high shares of migrant workers, so-called niche employment. The latter can lead to suboptimal working conditions including over-qualification and low wages.

Recent migrants from Central and Eastern Europe might be particularly interesting for our research topic as they tend to be high educated and young compared to previous waves of migrant workers. Migrant workers with high education levels naturally have a higher chance to experience over-qualification and, concurrently, larger wage gaps compared to nationals with similar education levels, given that migrant niche employment is often based in sectors and occupations that formally require comparatively low levels of education such as hospitality, private household services, agriculture and construction. The fact that many recent CEE migrants also tend to be young might put them at a double disadvantage (recent migrant and young) in the destination labor market. Youth have particular problems in entering (quality) employment as they lack work experience which allows them to signal to potential employers. Moreover, migrants, and in particular recent migrants are likely to be faced with additional challenges such as a lack in sufficient destination country language skills, problems with having their 
qualifications obtained abroad recognized and potentially direct discrimination by origin. Young recent migrants might therefore have to rely more heavily on social networks of established migrant communities who tend to be based in migrant niche employment.

Much of the current research on migrant outcomes and social networks is based on qualitative research. The few available quantitative papers on the issue are often single country studies given that information on social networks is not commonly available in comparative data sets with high enough case numbers to analyze (recent) migrant workers separately. By making use of the 2014 special module on migrants and their descendants of the European Labour Force Survey (EU-LFS) this paper can adopt a comparative perspective regarding destination country groups. Furthermore, the data allows looking at a specific subgroup of migrants - recent youth migrants from CEE countries and thus study this topic in a context of intra EU mobility. The advantage of the special module is that it not only includes information on how migrants found their current job including the use of social networks (relatives, friends or acquaintances) but also a subjective measure on over-qualification, our main dependent variable. Given the existence of immigrant occupation niches, the standard measures on over-qualification are problematic in that they are usually based on occupational information. Furthermore, beyond the standard demographics and employment characteristics which we need to take into account as the impact of social networks is likely to vary across individual and job characteristics, the data also includes information on language competences and other barriers preventing a person to have a job corresponding with their qualifications. These include a lack of recognition of qualifications obtained abroad and discrimination by origin, factors that are likely to be important mediators regarding the impact of social network support in findings employment on the respective qualitative employment outcomes.

The focus of our paper is intra EU labour mobility in a context of EU enlargement to a number of considerably less affluent countries with large wage gaps as compared to EU15 and EFTA member states and limited labour market prospects particularly for young workers in a number of these countries. Mobile EU workers are a very specific group of migrants; they are privileged as compared to third country migrants as they enjoy unrestricted access to EU and EFTA country labour markets - particularly after transitions measures have run out for citizens whose countries joined the EU in 2004 and 2007. ${ }^{2}$ Various EU regulations and directives as well as court rulings support the working conditions and social rights of intra EU migrants. This has to be kept in mind when interpreting the findings. Aguilera and Massey (2003) for example show for male Mexican workers in the US that the impact of social capital on employment outcomes such as formal employment is larger for undocumented than for legal migrants (see also Gavanas 2013).

The paper proceeds as follows: Section 1 briefly revises the relevant theory and literature on the role of social networks in employment outcomes of migrant workers. Section 2 explains the most relevant concepts and definitions which form the basis of our empirical analysis. Section 3 provides descriptive results on the use of social networks of recent EU migrant workers and their impact on qualitative employment outcomes distinguishing between young and older workers.

\footnotetext{
${ }^{2}$ EU countries had the option to use transitions measures vis-à-vis citizens of countries joining the EU - and thereby restrict free access to their labour markets - for up to 7 years. In practice this means that countries apply national law regarding access of EU workers from the respective accession countries to their labour markets and can require work permits (http://ec.europa.eu/social/main.jsp?catId=1067\&langId=en). In 2014 (base year of data) 13 Member States applied restrictions regarding free labour mobility for Croatian citizens (AT, BE, CY, FR, DE, GR, IT, LU, MT, NL, ES, SI and UK).
} 
We also provide descriptive results for nationals in order to assess if the impact on quality of employment of social networks differs between migrants and nationals. Section 4 discusses the results in light of the existing literature and concludes.

\section{Theory and brief literature review}

Neo-classical economic theories of migration emphasize net economic advantages and in particular wage differentials as main driver of migration. Looking into reasons for intraEuropean migration based on information from a range of data sets, Mau and Verwiebe (2010, figure 13.3) highlight however that social and family-related reasons are often at a par with economic and professional reasons for migration. Similarly, Janicka and Kaczmarczyk (2016) in their paper on Polish migrants' response to crisis-driven change also point to the importance of wider migration strategies beyond economic reasons impacting on patterns of behavior regarding return or settlement and labour market integration. They point in particular to transnational social ties as risk management devices especially in times of crises.

For the focus of our paper a combination of migration network theories and dual labour market theories seem pertinent. Migration network theories widen the context from the focus on the family and household at the country of origin as proponed by theories of new economics of labour migration (Stark and Bloom 1985) by including social networks in the destination country that comprise family but also friends and acquaintances. Social networks of migrants are typically specified as migrant ethnic networks but they can also include networks beyond ethnic ones. These networks constitute a form of social capital and reduce the costs and risks relating to immigration by providing information and resources as well as facilitating employment (Arango 2000). They constitute a link between individual level decision making regarding migration and macro-level structural determinants both at the country of origin and country of destination side (ibid). Migration network theories suggest that current migration patterns are influence by earlier migration patterns and will not be easily stopped by economic or policy change (Massey et al. 1993; Castles 2000). Krissman (2005) points out that this approach disregards important actors beyond the migrant network such as employers and recruitment agencies (on different types of migrant networks see also Vasta 2004). Indeed, regarding facilitating access to employment, labour networks (private and public employment intermediaries) can take over similar functions as social migration networks by substituting or complementing them (e.g. Samaluk 2016; Friberg \& Eldring 2013). ${ }^{3}$

Dual labour market theories (Piore 1979), in turn, emphasize pull-factors by pointing to the demand for immigrants in the destination country which is often situated in occupations with low status and wages. The dual labour market or segmentation approach initially focused mainly on job characteristics and not on the specific features of individuals or wider labour market characteristics such as labour and welfare state institutions. It thus predominantly pointed to the

\footnotetext{
${ }^{3}$ There is a broad literature on the impact of labour market intermediaries on employment and working conditions including with a focus on migrant workers. As with the literature on the role of social migration networks, naturally due to their main function which is matching positive impacts on employment are usually evident. The findings on the impact on working conditions are much more mixed and vary across skills and occupational sectors (e.g. Hyggen et al. 2016). Particularly private employment intermediaries such as temp agencies and firm posting workers are known to lead to sub-standard working conditions including lower wages (e.g. with a focus on CEE workers in Nordic countries see Friberg and Eldring 2013; for Polish workers in Oslo, Copenhagen and Reykjavik see Friberg et al. 2014; for migrants from Central and Eastern Europe in Britain see McCollum \& Findlay 2015).
} 
demand side of the labour market. Recent developments - 'third generation approaches' - pursue a more multidimensional approach and amongst other things also take into account labour supply as well as state actions and institutional features of labour markets (e.g. Peck 1996; Rubery 2007). Immigrant niches (for an extensive review of the relevant literature see Joassart-Marcelli 2014) which have been identified for certain economic sectors and occupations provide a link between the social network and dual labour market theories.

In the following we briefly review the available literature on the role of social networks in impacting on working conditions of (recent) migrant workers distinguishing between qualitative and quantitative approaches.

There are a number of quantitative studies based on individual or household survey data looking at the role of social networks in employment outcomes for undocumented and legal Mexican workers in the US (e.g. Aguilera and Massey 2003; Joassart-Marcelli 2014 with a gender perspective). Joassart-Marcelli (2014) shows that recent Mexican immigrants in Los Angeles who have found a job by way of social networks (family, friends, or acquaintances) are more likely to work in an occupational niche and earn lower wages than recent migrants who found work through different means. While this effect is evident for both men and women the analysis shows that women are particularly disadvantaged in that they are more likely to depend on social networks which are proximate (e.g. spouses) and the information they get tends to give access to employment which is segregated and low-wage. The study by Aguilera and Massey (2003) shows for male Mexican workers in the US that finding a job through a social network has no significant impact on sector of employment (formal or informal) for legal migrants whereas it has a positive impact for undocumented migrants. For our study the findings on legal migrants are more relevant given the specific EU cross-border labour mobility setting with (relatively) free labour mobility particularly after the end of transition periods. Aguilera and Massey (2003) are not primarily interested in the effect of job search strategy (social networks or not) on wages but rather on the role of social capital which is specified in terms of availability and proximity of social ties. The model (table 4, p. 688) indicates though that there are no significant effects on neither legal or undocumented migrants of having found a job through social networks on wages.

There are few relevant quantitative studies focusing on intra-EU labour mobility in a post 2004 enlargement setting. The main explanation is the absence of readily available data which both contains large enough case numbers on recent EU migrant workers and information on social networks as job finding device. ${ }^{4}$ Kalter (2011) who uses the Polish Migration Project data which is modelled on the Mexican data among others used by Aguilera and Massey (2003) to focus on Poles in Germany does look at the impact of social capital on the decision to temporarily migrate from Poland to Germany. Qualitative employment outcomes are not in focus. The study by Verwiebe et al. (2015) on commuters from Central Eastern European countries bordering Austria comes closest to our paper. The analysis framework is inspired by Aguilera and Massey (2003). It does find a small positive effect on wages of commuters to Austria of having found a job via social networks as compared to other job-finding methods.

There are a number of qualitative studies on recent EU migrants and social networks, most of which focus on Polish workers in the UK and particularly London. They address a range of

\footnotetext{
${ }^{4}$ Kahanec and Zimmermann (2016) use population stocks of the previous year to get a sense of the role of migration networks in migration movements from Central and Eastern Europe to Western Europe - however for the purpose of linking employment outcomes to social networks such a measure is insufficient.
} 
questions including why some migrants become entrepreneurs and other migrants co-ethnic workers (Knight 2015) and the relationship between ethnicity and social class with a focus on transnational chains (Eade et al. 2007). Ryan (2011) focusses on the impact of free labour mobility on the accessibility and necessity of the use of social networks including transnational ones. Gavanas (2013) analyses the household care sector in Sweden with a view on recent migrants with various ethnic backgrounds including from Eastern Europe. She characterises social networks as a crucial resource in the migration process including "strategies for work, welfare, social participation and resistance" (ibid, p. 61).

Another important distinction that emerges from the relevant literature is the unit of analysis. In our paper the main focus is the individual and the intermediating function of the social networks on their qualitative employment outcomes (see also Verwiebe et al. 2015; Joassart-Marcelli 2014). Other studies and in particular those focusing on transnational networks are more interested in the household dimension of social networks (e.g. Ryan 2011; Eade et al. 2007). Last but not least, a number of studies put the core focus on the size and composition of the social network (proximity, co-ethics or nationals from destination country, etc.) and what this implies for individual outcomes including in terms of employment (e.g. Aguilera and Massey 2003; Verwiebe et al. 2015; Verhaeghe et al. 2015 for school to work transitions of North African ethnic minorities in Belgium).

\section{Concepts and definitions}

This article looks at EU cross border labour mobility of migrants from Central and Eastern European (CEE) countries which joined the EU in 2004 (Czech Republic, Estonia, Hungary, Latvia, Lithuania, Poland, Slovakia, and Slovenia) ${ }^{5}, 2007$ (Bulgaria and Romania) and 2013 (Croatia). Unfortunately, the Eurostat data does not allow looking at these countries or country groups separately or excluding Croatia for example the citizens of which still are under transition measure restrictions with regard to a number of destination countries. Spreckelsen et al. (2016) have shown though that recent EU10 \& EU2 migrants display worse qualitative labour market outcomes in Germany and the UK than migrants from the EU-South and particularly the EUWest and North. Kurekova (2013) however also emphasizes the differences in post-accession out-migration from CEE countries with a view on country of origin welfare state institutions.

Regarding destination countries, we focus on EU15 countries, Switzerland and Norway. The data allows looking separately at different welfare regimes - but due to low case numbers not at single destination countries. Using a welfare regime approach to destination countries seems pertinent given the variation in labour regulation and institutional settings, economic situation and language and cultural proximity which are known to impact on the entry of migrants to the respective country of destination, their access to employment and working conditions and might also have an impact on the mediating role of social networks on labour market outcomes (see Pellizzari 2010, on European cross-country differences on the impact of social networks on wages though not with a focus on migrant workers). ${ }^{6}$ Notwithstanding shortcomings and limitations (Arts \& Gelissen 2002) we follow the standard welfare regime literature (Esping Andersen 1990, Ferrera 1995) distinguishing between Continental countries (Austria, Belgium,

\footnotetext{
${ }^{5}$ Citizens of Malta and Cyprus are also included in the data but their numbers are negligible.

6 See for example Pellizzari (2010) on European cross-country differences by labour market efficiency on the impact of social networks on wages though not with a focus on migrant workers.
} 
Switzerland ${ }^{7}$, France and Luxembourg), Mediterranean countries (Spain, Greece, Italy, Portugal), Nordic (Finland, Norway, Sweden) and Anglo-Saxon (UK) welfare regimes. ${ }^{8}$

Our focus is on recent migrants, and more particularly those who have arrived in the respective destination country group in the previous 5 years (Rienzo 2013; Joassart-Marcelli 2014; Ryan 2011). The focus on recent migrants provides a better opportunity to investigate the impact of social networks on over-qualification and wages, as these would be less relevant for established migrants who potentially already experienced a catch-up or assimilation with their national peers by way of accumulation of country of destination specific capital over time (e.g. Kalter 2011). Friberg et al. (2014) for example find for Polish migrants in Norway that there is a positive and significant effect of length of stay on wages; this effect is much weaker for Denmark.

We look separately at youth (20-29 years) and older migrants (30-65 years). Recent migrants from Central and Eastern Europe moving to EU15 and EFTA destination countries have been shown to be comparatively high qualified and young (European Integration Consortium 2009). They might thus be at a double or even triple disadvantage. First, high qualified youth by definition are at a particular high risk of taking up a job that is below their skills level. Second, migrant workers - even though EU migrants being privileged vis-a-vis third country migrants have limited information on the destination country's labour market and are likely to face additional barriers such as lack of language skills, problems with recognition of qualifications from their home country and potentially direct discrimination. Third, youth have particular problems in entering (quality) employment as they lack work experience which they could use to signal to employers. They might therefor have to rely more on social networks of established migrant communities.

\section{Data and research strategy}

We use the individual level data of the European Labour Force Survey (EU-LFS). It is a large representative household sample survey providing quarterly results on labour market participation of the population age 15 and over as well as of persons outside the labour force. It covers the 28 EU countries as well as three EFTA countries. It's a harmonized data set using the same concepts and definitions across countries. Its sample size and the availability of harmonized data make it possible to study the outcomes of sub-populations such as EU migrant workers across Europe. ${ }^{9}$ Our main focus in on the 2014 data and in particular the special ad hoc module on the labour market situation of migrants and their immediate descendants. An advantage of using 2014 data is that with the exception of Croatian nationals, Central and Eastern European nationals had free access to all EU15 and EFTA labour markets at this point in time. This makes comparisons across destination country groups easier as we do not have to take into account variation in regulation of labour market access due to transitional measures in our analysis and/or interpretation of results. However, considering only data of 2014 leads to rather

\footnotetext{
${ }^{7}$ We include EFTA countries with available information in the destination countries as the EU free labour mobility regime applies to them as well.

8 A number of countries did not participate in the special module (e.g. Ireland, Denmark) or did not make the data available to Eurostat (Germany).

${ }^{9}$ For more information on the EU-LFS see http://ec.europa.eu/eurostat/web/microdata/european-union-labour-forcesurvey. For more information on the special module 2014 see http://ec.europa.eu/eurostat/statisticsexplained/index.php/EU_labour_force_survey_-_ad_hoc_modules.
} 
small sample sizes of recent NMS13 migrants per country, requiring us to cluster countries in welfare regime types (see Table 1). For contextual information on population stocks of migrants in EU15 countries, Switzerland and Norway we use the EU-LFS data from 2005 to 2014 (see Table 1).

Table 1: Weighted numbers of NMS10, NMS3 and (recent) NMS13 migrants in EU15 countries, Switzerland and Norway and country clusters in 2005 and 2014

\begin{tabular}{|c|c|c|c|c|c|c|c|c|c|c|}
\hline & \multicolumn{5}{|c|}{2005} & \multicolumn{5}{|c|}{2014} \\
\hline & $\begin{array}{c}\text { NMS } \\
10\end{array}$ & $\begin{array}{c}\text { NMS } \\
3\end{array}$ & $\begin{array}{c}\text { NMS } \\
13\end{array}$ & $\begin{array}{c}\% \text { NMS13 } \\
\text { of } \\
\text { population }\end{array}$ & $\begin{array}{l}\text { Recent } \\
\text { NMS13 }\end{array}$ & $\begin{array}{c}\text { NMS } \\
10\end{array}$ & $\begin{array}{c}\text { NMS } \\
3\end{array}$ & $\begin{array}{c}\text { NMS } \\
13\end{array}$ & $\begin{array}{c}\% \text { NMS13 } \\
\text { of } \\
\text { population }\end{array}$ & $\begin{array}{l}\text { Recent } \\
\text { NMS13 }\end{array}$ \\
\hline Austria (AT) & 62 & 95 & 157 & $1,93 \%$ & 34 & 134 & 164 & 298 & $3,54 \%$ & 93 \\
\hline Belgium (BE) & 21 & 9 & 30 & $0,29 \%$ & 15 & 75 & 76 & 151 & $1,35 \%$ & 88 \\
\hline Switzerland $(\mathrm{CH})$ & 17 & 38 & 55 & $0,89 \%$ & 13 & 50 & 40 & 90 & $1,30 \%$ & 34 \\
\hline Germany (DE) & 442 & 415 & 857 & $1,03 \%$ & 193 & 779 & 572 & 1351 & $1,65 \%$ & 549 \\
\hline France (FR) & 37 & 17 & 54 & $0,09 \%$ & 15 & 37 & 108 & 145 & $0,23 \%$ & 45 \\
\hline Luxembourg (LU) & 1 & 1 & 2 & $0,44 \%$ & 0 & 8 & 3 & 11 & $2,04 \%$ & 4 \\
\hline Netherlands (NL) & 15 & 5 & 20 & $0,12 \%$ & 9 & 95 & 8 & 103 & $0,62 \%$ & 25 \\
\hline Continental countries & 595 & 580 & 1175 & $0,64 \%$ & 279 & 1178 & 971 & 2149 & $1,13 \%$ & 838 \\
\hline Spain (ES) & 60 & 481 & 541 & $1,25 \%$ & 395 & 94 & 769 & 863 & $1,88 \%$ & 46 \\
\hline Greece (GR) & 36 & 46 & 82 & $0,75 \%$ & 36 & 31 & 70 & 101 & $0,93 \%$ & 17 \\
\hline Italy (IT) & 52 & 273 & 325 & $0,56 \%$ & 173 & 134 & 1161 & 1295 & $2,14 \%$ & 146 \\
\hline Portugal (PT) & 1 & 12 & 13 & $0,12 \%$ & 10 & 1 & 20 & 21 & $0,20 \%$ & 3 \\
\hline Mediterranean countries & 149 & 812 & 961 & $0,78 \%$ & 614 & 260 & 2020 & 2280 & $1,79 \%$ & 212 \\
\hline Denmark (DK) & 6 & 2 & 8 & $0,15 \%$ & 3 & 47 & 21 & 68 & $1,21 \%$ & 38 \\
\hline Finland (FI) & a & a & 16 & $0,31 \%$ & 3 & a & a & 37 & $0,68 \%$ & 5 \\
\hline Norway (NO) & 5 & 3 & 8 & $0,24 \%$ & 4 & 82 & 9 & 91 & $2,36 \%$ & 56 \\
\hline Sweden (SE) & a & a & 23 & $0,25 \%$ & 9 & a & a & 61 & $0,85 \%$ & 30 \\
\hline Nordic countries & & & 55 & $0,24 \%$ & 19 & & & 257 & $1,16 \%$ & 129 \\
\hline Ireland (IE) & 59 & 8 & 67 & $1,62 \%$ & 63 & 210 & 22 & 232 & $5,03 \%$ & 49 \\
\hline United Kingdom (UK) & 204 & 33 & 237 & $0,40 \%$ & 170 & 1379 & 239 & 1618 & $2,54 \%$ & 651 \\
\hline Anglo-Saxon countries & 263 & 41 & 304 & $0,48 \%$ & 233 & 1589 & 261 & 1850 & $2,71 \%$ & 700 \\
\hline
\end{tabular}

Source: European Labour Force Survey (EU-LFS) 2015; EU15 countries (plus Switzerland and Norway).

${ }^{a}$ Information for NMS3 and NMS10 migrants is not available in the LFS data.

Between 2005 and 2014 population stocks of migrants from NMS13 countries have increased within all EU15 countries, Switzerland and Norway (see Table 1). The number of recent migrants has also grown in most European countries with exception of Mediterranean countries. As these countries were strongly affected by the economic crisis followed by extremely high (youth) unemployment rates, not surprisingly, those labour markets have become less attractive for migrants seeking work (see also Figure 1). 

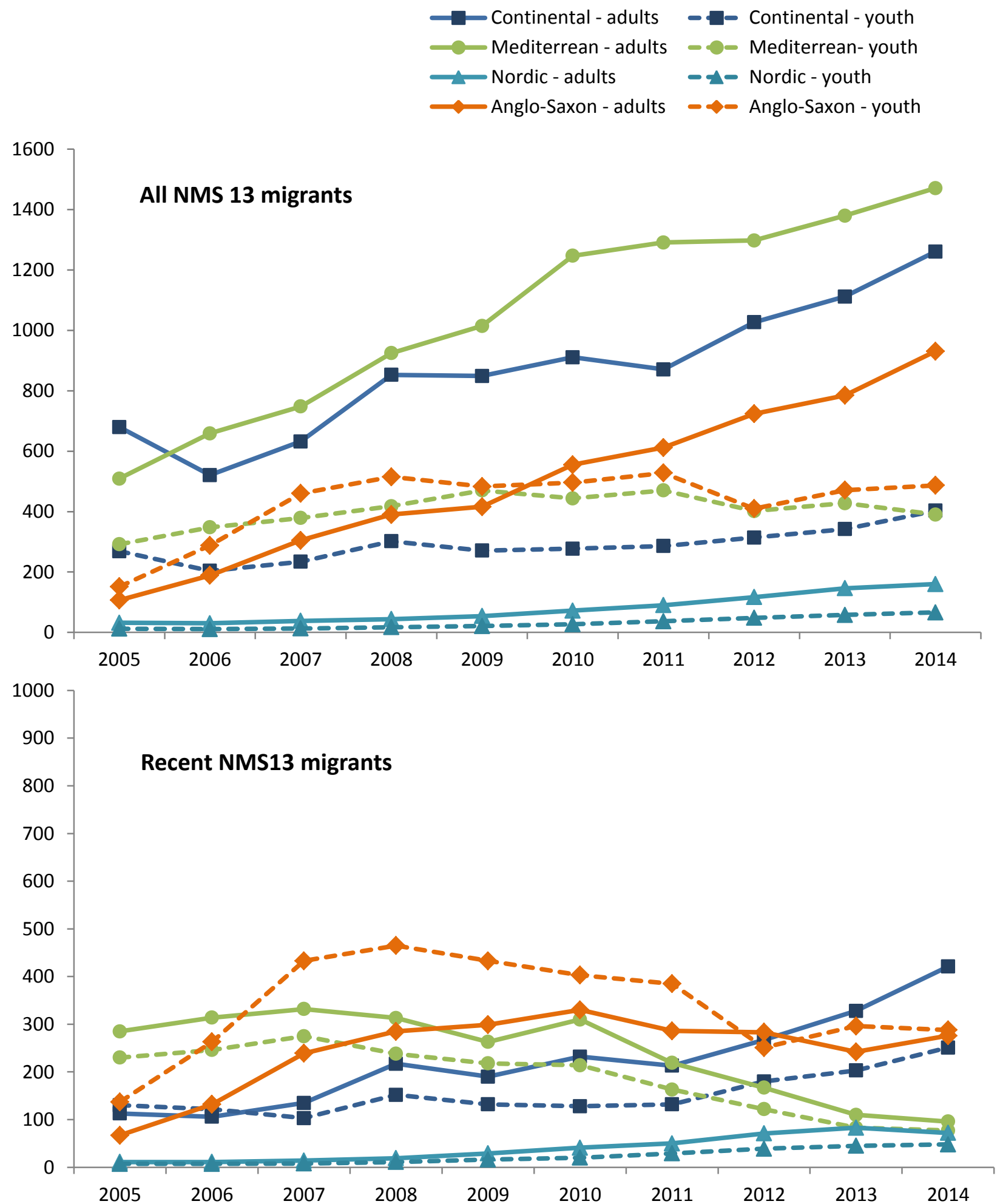

Figure 1: (Recent) NMS13 migrants in different European country clusters from 2005 to 2014 -youth (2029 years) and adults (30-65 years); weighted numbers.

Source: European Labour Force Survey (EU-LFS) 2015; EU15 countries (plus Switzerland and Norway). 
The overall number of NMS13 migrants has increased continuously from 2005 to 2014 in all country clusters (see Figure 1). However, the number of recent NMS13 migrants has decreased in Mediterranean countries. They used to be particularly attractive for Nationals from Romania and Bulgaria but given that these countries have been hit hard by the economic crisis - Spain even reintroduced transition measures for Romanian citizens at the peak of the crisis - they have become a less attractive destination for migrant workers in terms of labour market opportunities. Since 2005, young NMS13 migrants have mainly been attracted to Anglo-Saxon countries, whereby this trend was in particular strong between 2007 and 2011. After lifting the labour market restrictions in Germany and Austria in 2011 the number of recent NMS13 migrants in the continental country cluster has continuously increased. A rather high share of recent NMS13 migrants is younger than 30 years old ${ }^{10}$ (see Figure 1). Furthermore, the majority of NMS13 migrants has come to EU15 and EFTA countries for employment reasons ${ }^{11}$. This is also visible indirectly in the high employment rate of recent NMS13 migrants - even though young migrants have lower employment rates than adults with exception of young migrants in the UK (see Figure 2).

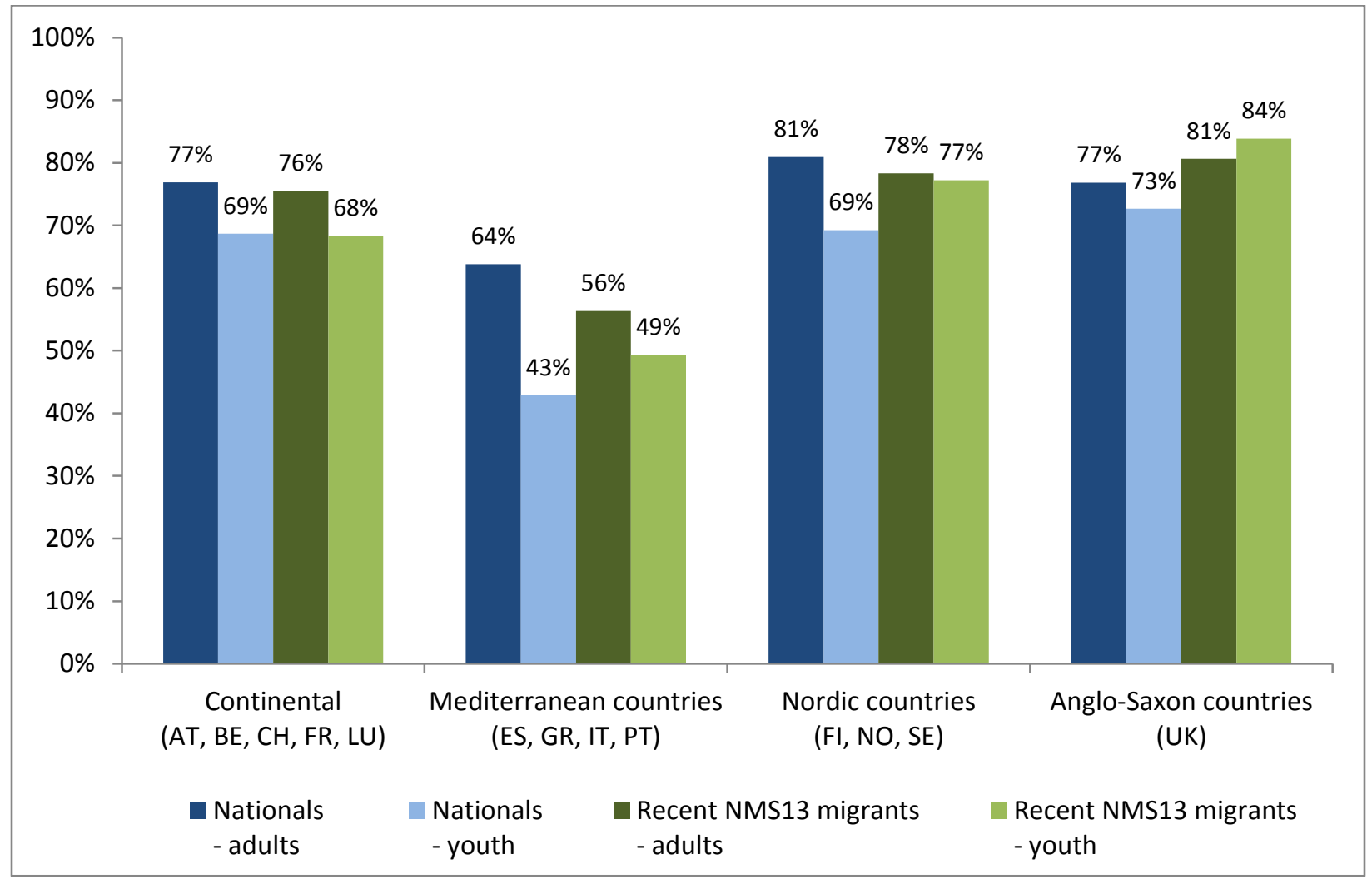

Figure 2: Employment rates of NMS13 migrants compared to nationals in different European country clusters in 2014 - youth (20-29 years) and adults (30-65 years); weighted numbers. Source: European Labour Force Survey (EU-LFS) 2015; EU15 countries (plus Switzerland and Norway).

\footnotetext{
${ }^{10}$ Considering that we compare a group with a small age band of 10 years (youth: 20 to 29 years) with a group with a larger age band of 25 years (adults: 30 to 64 years) the share of young migrants is relatively high.

${ }^{11}$ More than 60 percent of the recent NMS13 migrants came to EU15 countries for employment reasons (EU-LFS 2014, not shown).
} 


\section{Job search strategies and labor market outcomes of young recent NMS13 migrants}

This section provides descriptive results on the use of social networks of recent NMS13 migrant workers and their impact on qualitative employment outcomes distinguishing between young and older workers. It also provides descriptive results for nationals in order to assess if the impact on quality of employment of social networks differs between migrants and nationals.

The following analyses are based on data of the special ad hoc module on the labour market situation of migrants and their immediate descendants. The advantage of the special module is that it includes a subjective measure on over-qualification, our main dependent variable. Given the existence of migrant employment niches, the standard measures on over-qualification are problematic in that they are usually based on occupational information. Importantly, the special module also contains information on how they found their current job including the use of social networks (relatives, friends or acquaintances), our main variable of interest. Furthermore, beyond the standard demographics and employment characteristics the data also includes information on language competences of migrants. Unfortunately, some countries did not participate to the special module (Denmark, Ireland, Netherlands) or do not provide data access to the module via Eurostat (Germany).

Table 2 provides an overview on different indicators comparing adult recent NMS13 migrants with adult nationals and young recent NMS13 migrants with young nationals.

Table 2: Descriptive statistics for recent NMS13 migrants compared to nationals - youth (20-29 years) and adults (30-65 years); weighted numbers.

\begin{tabular}{|l|c|c|c|c|}
\hline & \multicolumn{2}{|c|}{ Nationals } & \multicolumn{2}{c|}{$\begin{array}{c}\text { Recent NMS13 } \\
\text { migrants }\end{array}$} \\
\hline & adult & Youth & adult & Youth \\
\hline Country cluster & & & & \\
\hline Anglo-Saxon (UK) & 20.0 & 23.6 & $48.0^{*}$ & $57.4^{*}$ \\
\hline Continental (AT, BE, CH, FR, LU) & 29.1 & 30.9 & $21.5^{*}$ & $18.7^{*}$ \\
\hline Mediterranean (ES, GR, IT, PT) & 44.2 & 38.4 & $18.6^{*}$ & $16.9^{*}$ \\
\hline Nordic (FI, NO, SE) & 6.7 & 7.2 & $11.9^{*}$ & 7.0 \\
\hline Industry & a & & & \\
\hline Agriculture, forestry and fishing & & & & \\
\hline Mining, energy and water & 3.2 & 1.9 & 4.4 & 3.0 \\
\hline Manufacturing & 1.8 & 1.3 & 1.0 & 1.0 \\
\hline Construction & 13.3 & 12.0 & 13.7 & $19.8^{*}$ \\
\hline Wholesale and retail trade & 6.3 & 7.0 & $12.5^{*}$ & 9.2 \\
\hline Gastronomy and accommodation & 12.9 & 18.6 & 11.2 & $12.0^{*}$ \\
\hline Transport and communication & 3.7 & 7.9 & $10.9 *$ & $21.0^{*}$ \\
\hline Financial, professional, or administrative services & 8.6 & 7.4 & 7.7 & 9.4 \\
\hline Public administration, education and health & 14.6 & 14.8 & 15.2 & 10.7 \\
\hline Other services & 30.3 & 22.3 & $11.1^{*}$ & $7.3^{*}$ \\
\hline Skill level & 5.2 & 6.6 & $12.3^{*}$ & 6.5 \\
\hline Low & & & & \\
\hline Medium & 31.0 & 17.6 & $20.8^{*}$ & 19.6 \\
\hline High & 38.1 & 51.7 & $49.2^{*}$ & 51.5 \\
\hline
\end{tabular}




\begin{tabular}{|l|c|c|c|c|}
\hline Employment rate & 70.7 & 58.6 & 73.7 & $75.5^{*}$ \\
\hline Working hours & 38.03 & 35.98 & 37.65 & $37.80^{*}$ \\
\hline High earning ( $^{\text {th }}$ to $10^{\text {th }}$ decile) & 57.5 & 30.4 & $24.1^{*}$ & $18.2^{*}$ \\
\hline Subjective over-qualification & 19.8 & 25.1 & $31.1^{*}$ & $42.9^{*}$ \\
\hline Job found mainly through social networks & 28.5 & 27.7 & $49.1^{*}$ & $40.2^{*}$ \\
\hline Gender & & & & \\
\hline Women & 50.7 & 49.1 & 51.3 & $56.6^{*}$ \\
\hline Men & 49.3 & 50.9 & 48.7 & $43.4^{*}$ \\
\hline Language proficiency & & & & \\
\hline Beginner or less & & & 36.2 & $26.8^{\mathrm{b}}$ \\
\hline Intermediate & & & 39.4 & 35.6 \\
\hline Advanced or first language & & & 24.4 & $37.6^{\mathrm{b}}$ \\
\hline Obstacles to get (skill-matched) employment & & & & \\
\hline No particular obstacle & & & 24.8 & 33.7 \\
\hline Lack of language skills & & & 34.7 & 24.5 \\
\hline Lack of recognition & & & 10.8 & 11.6 \\
\hline Restricted right to work & & & 3.2 & 4.0 \\
\hline Origin, religion or social background & & & 5.1 & 3.1 \\
\hline Other obstacles & & & 21.4 & 23.0 \\
\hline (Weighted) N & 130,846 & 31,444 & 537 & 468 \\
\hline
\end{tabular}

Source: European Labour Force Survey (EU-LFS) - Ad hoc module 2014.

${ }^{a}$ For more information on industries see Table 4 in the appendix.

* (Logistic) regression analysis revealed a significant effect in comparison of adult recent NMS13 migrants with adult nationals or of young recent NMS13 migrants with young nationals; $p<.05$, with Bonferroni correction.

${ }^{b}$ Logistic regression analysis revealed a significant effect in comparison of young and adult recent NMS13 migrants; $p<.05$, with Bonferroni correction.

Young recent NMS 13 migrants more often work in manufacturing or the hospitality industry (Table 2), but less often work in the wholesale industry or in the public, educational or health sector compared to young nationals. Adult recent NMS13 migrants more often work in construction, in the hospitality industry or in other services, less often work in the public, educational or health sector compared to adult nationals. The skill level of young recent migrants is comparable to the one of national youth. However, adult NMS13 migrants are less often low skilled and more often medium skilled compared to adult nationals. Compared to young nationals, young recent NMS13 migrants have a much higher employment rate (except in continental countries - see figure 2) and work more hours per week. Interestingly, the share of women is comparatively high in the group of young recent NMS13 migrants. Young NMS13 migrants have a higher host countries' language proficiency than older migrants. Accordingly, older NMS13 migrants claim more often that the lack of language skills is the main barrier to get a job at all or one that matches their qualifications, even if this effect does not reach statistical significance after the Bonferroni correction. Still, a quarter of young recent NMS13 migrants mention lack of language skills as main barrier. 


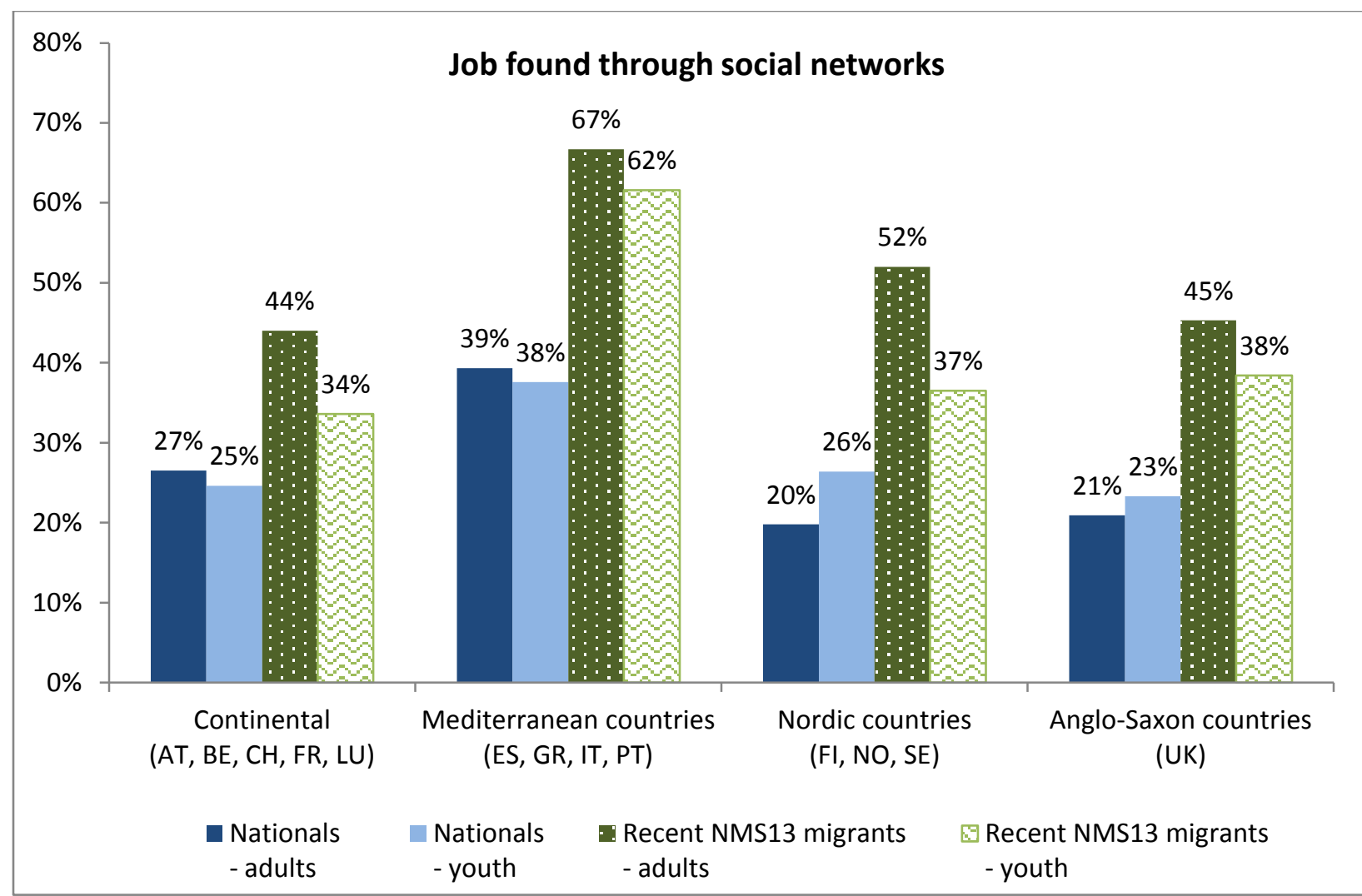

Figure 3: Rates of employees that found the current job through social networks for youth and adult recent NMS13 migrants compared to nationals in different European country clusters in 2014, weighted numbers. Source: European Labour Force Survey (EU-LFS) - Ad hoc module 2014.

In all European country clusters recent NMS13 migrants more often found their current job through social networks than nationals did; this strategy was more pronounced for adults than for youth (see Figure 3). This is surprising because in principle recent migrants should have less access to social networks than nationals have. However, assuming that they are for the most part less acquainted with the destination country's labour market and how to access it including direct contact with employers or access via public employment services, they are in higher need of using social networks which are often migrants from the same country of origin who have already established themselves (Eade et al. 2007). Temporary work agencies have also made use of this information deficiency including direct recruitment in the country of origin (Napierała and Fiałkowska 2013). The social network job findings strategy seems to be particularly evident in the Mediterranean cluster with a comparatively difficult labour market situation. 


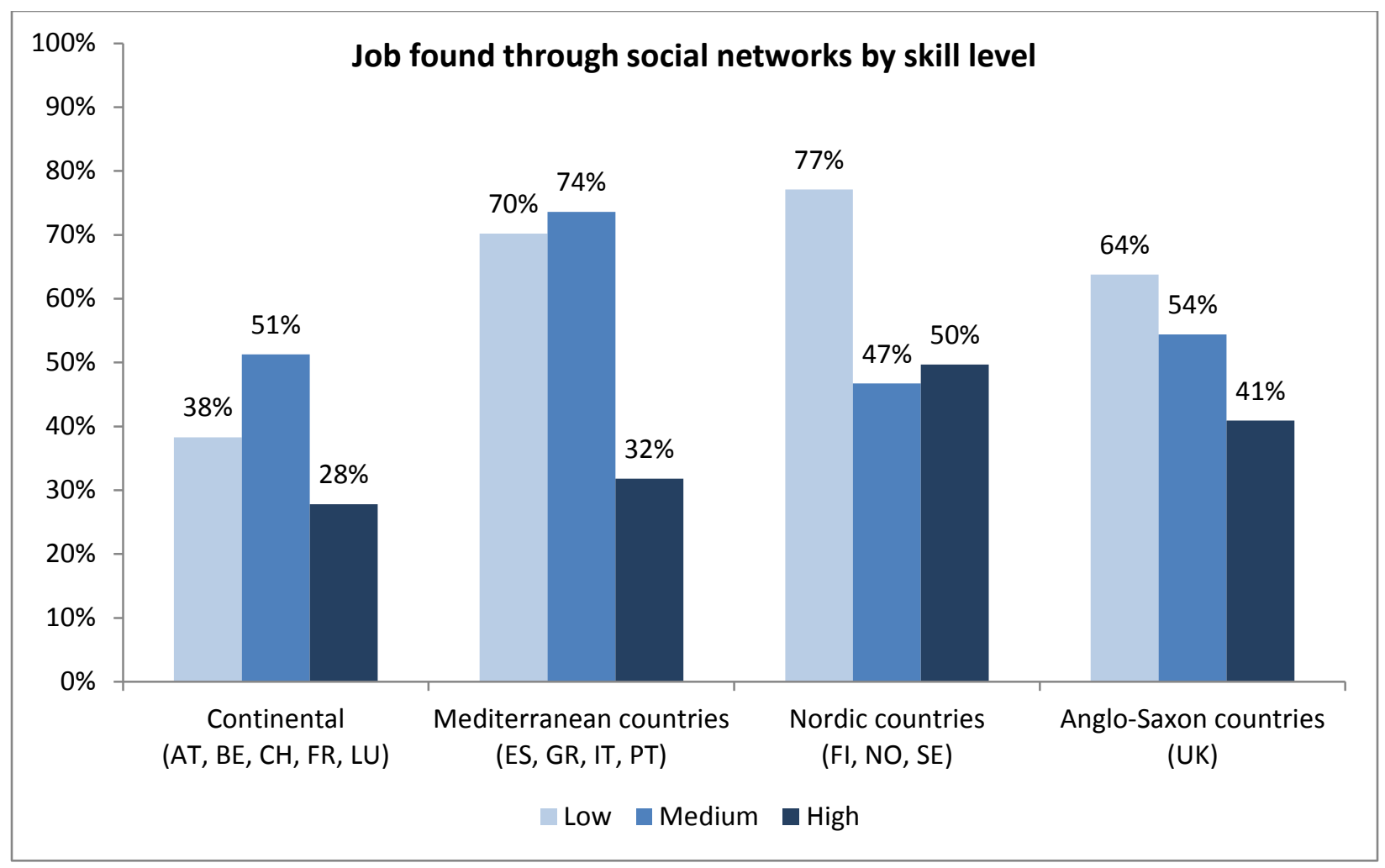

Figure 4: Rates of employees that found the current job through social networks for recent NMS13 migrants with different skill level in different European country clusters in 2014, weighted numbers. Source: European Labour Force Survey (EU-LFS) - Ad hoc module 2014.

The job search strategy depends on the skill level: across all European country clusters low skilled NMS13 migrants compared to high skilled migrants more often used social networks to find their job (Figure 4). The finding for the Continental cluster that social networks are most important for medium qualified is also confirmed by Verwiebe et al. (2015) who look at crossborder commuters from Central and Eastern Europe to Austria. Social network job findings strategies are more common among young recent NMS migrants in Nordic countries than in the other clusters which might have to do with language challenges. 


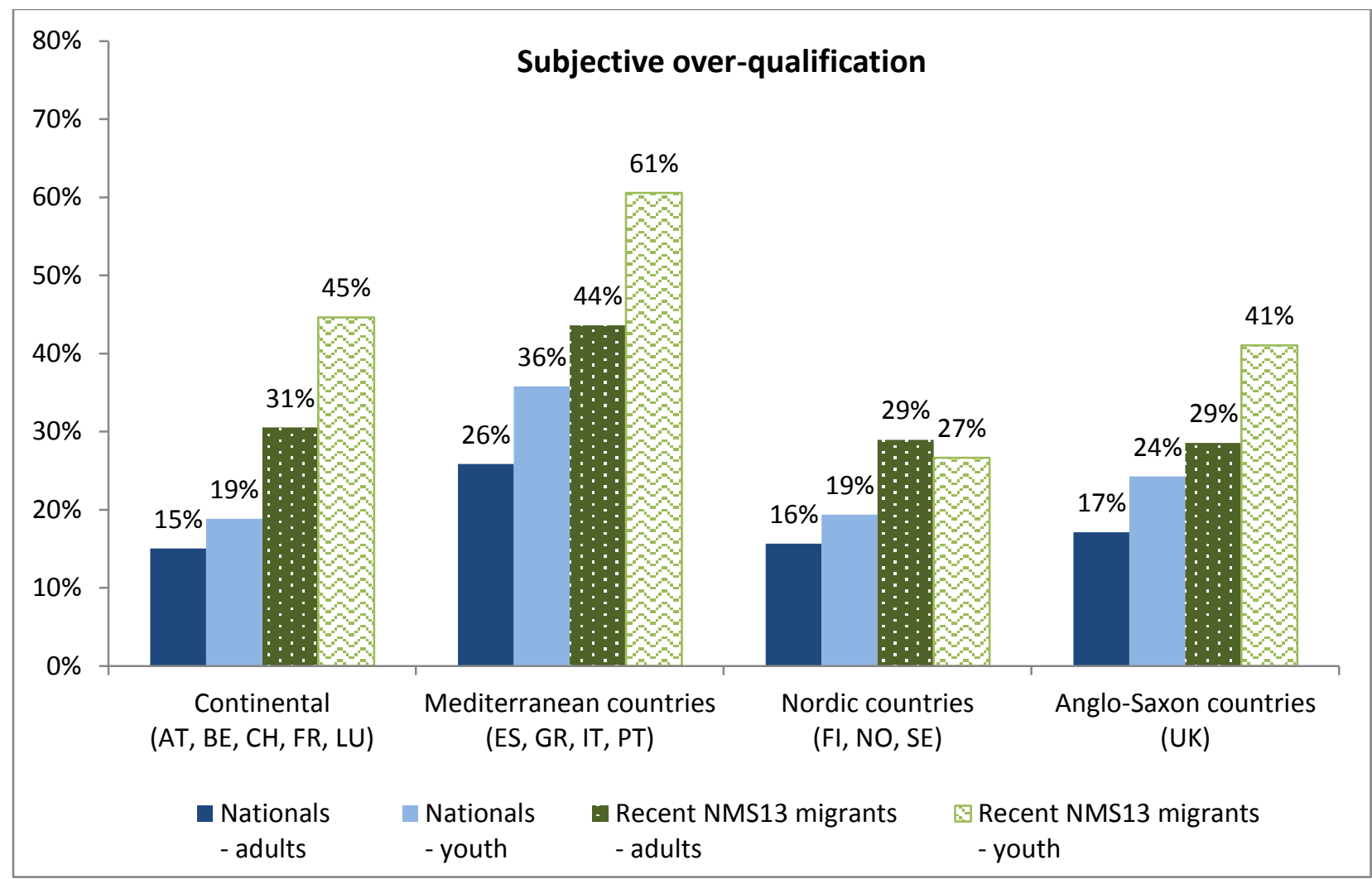

Figure 5: Subjectively perceived over-qualification rates for youth and adult recent NMS13 migrants compared to nationals in different European country clusters in 2014, weighted numbers. Source: European Labour Force Survey (EU-LFS) - Ad hoc module 2014.

In Figure 5 we see that NMS13 migrants are more often over-qualified for their jobs than nationals are. With the exception of Nordic countries with comparatively good labour market opportunities due to shortages in some sectors (particularly services and construction) and occupations (see European Parliament 2015) young recent NMS13 migrants have the highest rates of over-qualification. ${ }^{12}$ In all country clusters, adult nationals have the lowest rates of overqualification. Similarly, Figure 6 shows that adult nationals are the group with the highest share of employees by far in the higher earnings group ${ }^{13}$. Young NMS13 migrants are the group with the lowest share. In the Nordic countries young recent NMS13 migrants seem to do similar on average to young nationals in terms of earnings and somewhat better than recent NMS13 adults.

\footnotetext{
12 Importantly, according to the European Parliament (2015) report several of the New Member States are among the countries reporting the highest sectoral shortages including construction, putting among others the effects of large scale outward migration into focus.

${ }^{13}$ EU-LFS data provides information on the "monthly (take home) pay from main job" only in the aggregated form of deciles. We used this variable to distinguish between a lower earnings group ( $1^{\text {th }}$ to $5^{\text {th }}$ decile) and a higher earnings group $\left(6^{\text {th }}\right.$ to $10^{\text {th }}$ decile).
} 


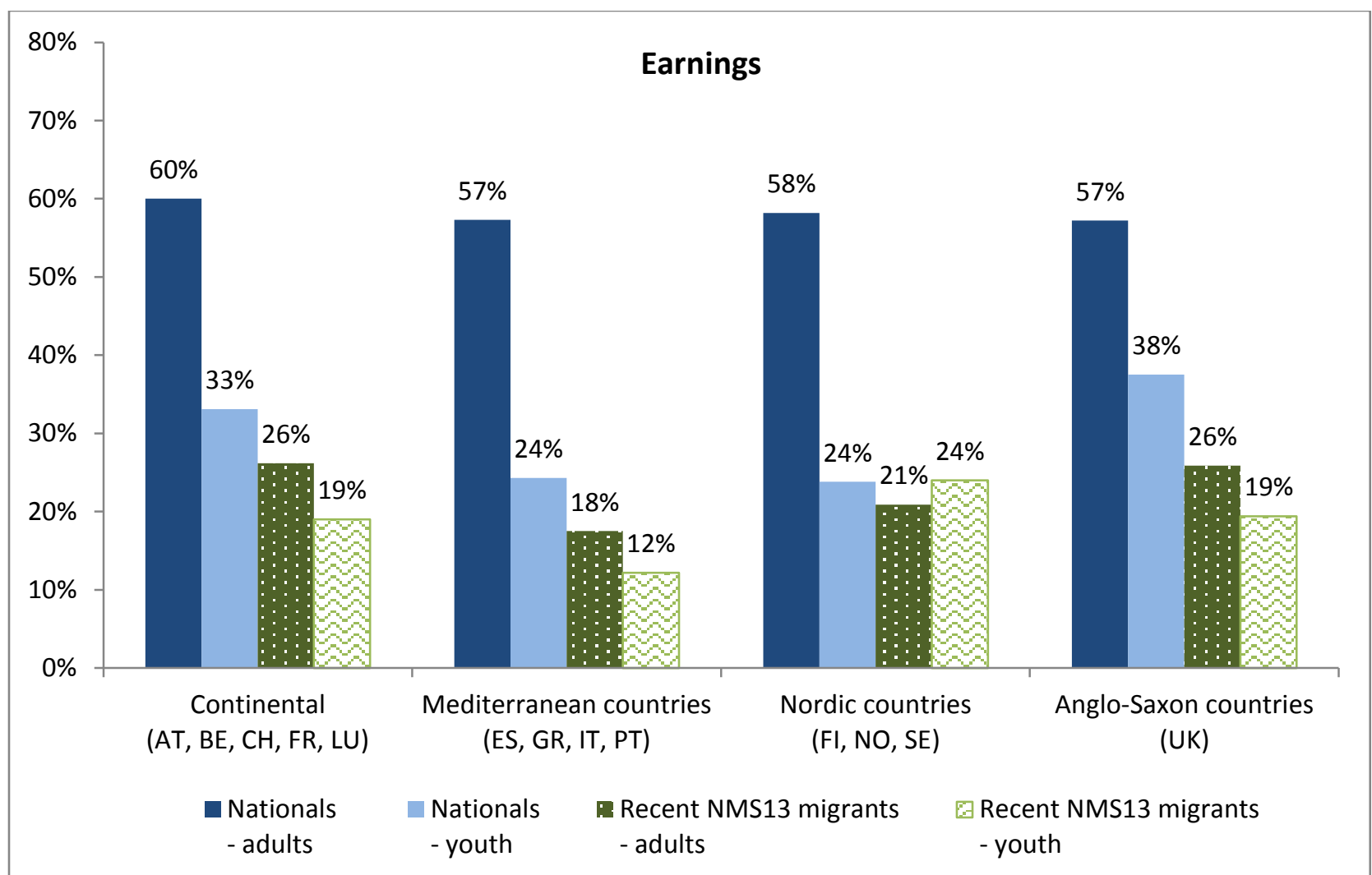

Figure 6: Rates of employees with higher earning (6th to 10th decile) for youth and adult recent NMS13 migrants compared to nationals in different European country clusters in 2014, weighted numbers. Source: European Labour Force Survey (EU-LFS) - Ad hoc module 2014.

To sum up, recent NMS13 migrants more often found their jobs by using social networks and at the same time they have poorer labour market outcomes than nationals for the most part. In particular, young recent migrants are affected rather often by over-qualification and most of them have rather low earnings. In the next step we descriptively examine the effect of the usage of social networks for job search on over-qualification and earnings (see Figure 7 and Figure 8). Due to low case numbers we do not do this separately for youth and adults regarding recent migrants. The following results thus look at the total age group (20-65 years). 


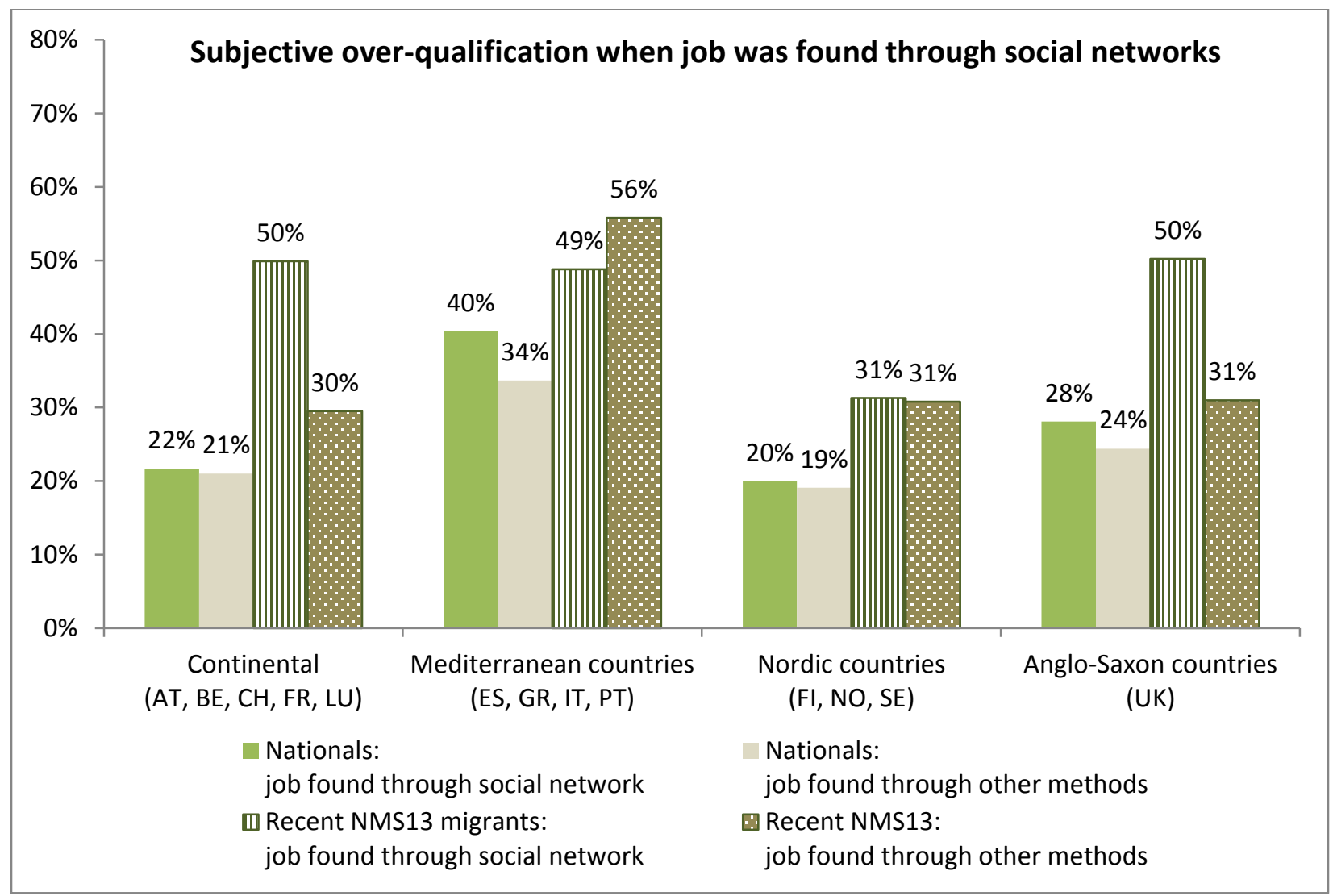

Figure 7: Subjectively perceived over-qualification rates when job was found through social networks compared to other job search strategies for recent NMS13 migrants and nationals in different European country clusters in 2014, weighted numbers.

Source: European Labour Force Survey (EU-LFS) - Ad hoc module 2014.

Note: Other methods include responding to advertisements, public employment services, private employment agencies, education or training institution, direct application with employer.

In Continental and Anglo-Saxon countries, recent NMS13 migrants who found their jobs through social networks are considerably more often over-qualified than nationals independent of job search strategy or recent NMS13 migrants who used other job search strategies (Figure 7). In Nordic countries the higher shares of over-qualified compared to nationals do not seem to be linked to the recent migrants' job search strategy. Recent NMS13 migrants in Mediterranean countries seem to benefit to some degree from job search strategies via social networks regarding over-qualification as compared to other job finding strategies taken together. 


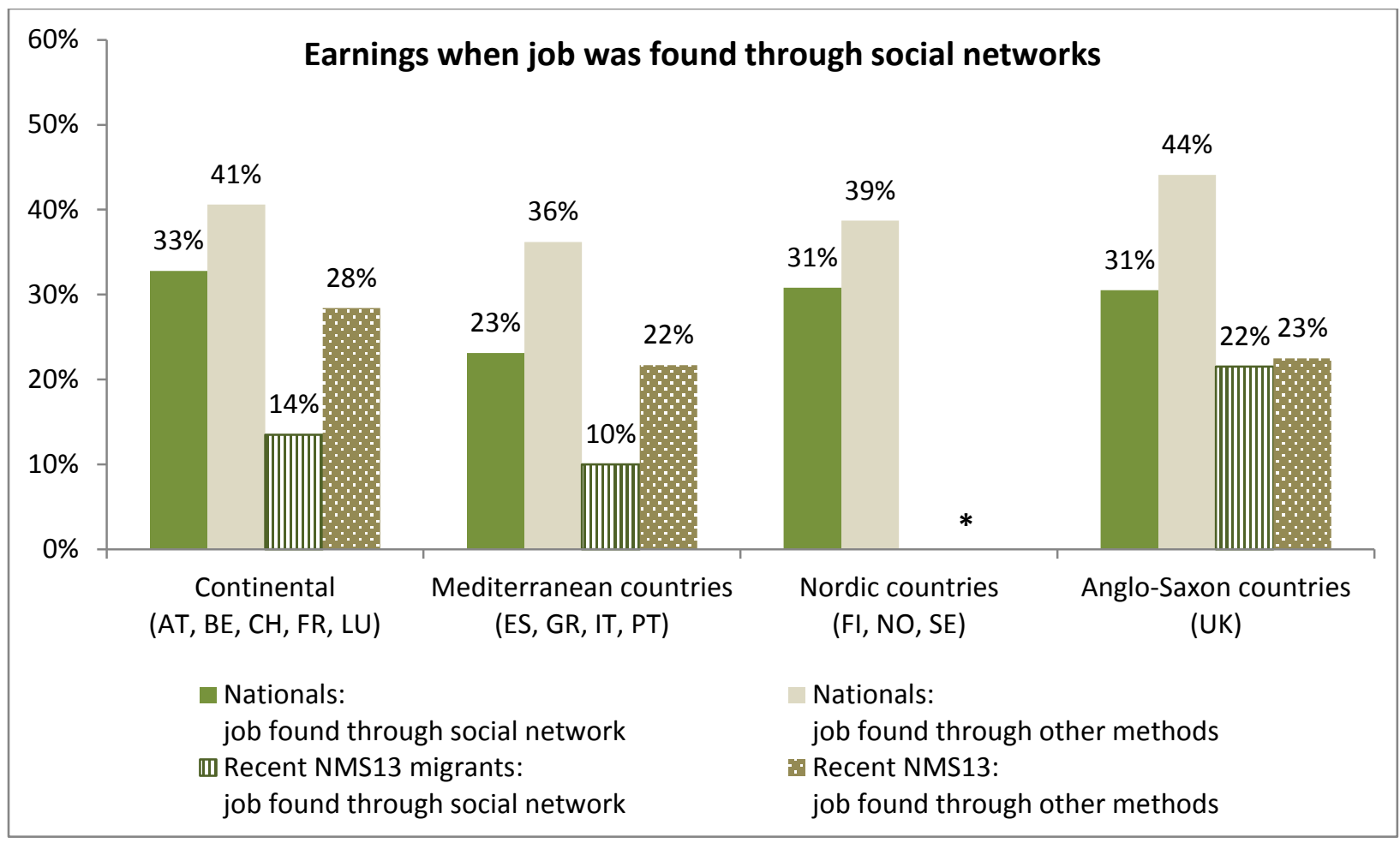

Figure 8: Rates of employees with higher earning (6th to 10th decile) when job was found through social networks compared to other job search strategies for recent NMS13 migrants and nationals in different European country clusters in 2014, weighted numbers.

*Cell sizes for recent NMS 13 migrants in Nordic countries are too small to report results.

Source: European Labour Force Survey (EU-LFS) - Ad hoc module 2014.

The earning is lower on average when a job was found through social networks - this holds true for both nationals and recent NMS13 migrants (Figure 8). The difference is largest in Continental countries while in Anglo-Saxon countries the difference in the earnings between recent NMS13 migrant groups that used social networks as compared to other job search strategies is only marginal. We have to bear in mind that mainly low skilled NMS13 migrants use social networks to find their job (Figure 4) and low skilled have, in general, jobs with lower earnings.

Descriptive data presented in this paper indicate that recent NMS13 migrants more often find their jobs using social networks. On the one hand, this strategy might be beneficial to find a job in the first place, an issue the data unfortunately does not allow us to test directly. On the other hand, there is evidence that using this job search strategy is often not beneficial concerning job quality. When recent NMS13 migrants found their jobs through social networks it is more likely that they are over-qualified for the position and that they fall in a lower earnings class as compared to recent migrants who used other job search methods. However, the results differ between different welfare regimes. In particular, in Continental countries the negative effects of the usage of social networks for job search is evident. In Anglo-Saxon countries the social network strategy that NMS13 migrants use is related to more over-qualification but not lower wages while in Mediterranean countries there is only a negative effect on earnings. For the Nordic countries we do not find any impact of the job search strategy on over-qualification, the case numbers unfortunately do not allow to look at the impact on earnings. 


\section{Conclusion}

After the 2004 accession round population stocks of immigrants from Central and Eastern Europe (NMS13 countries) have increased within in all EU15 countries, Switzerland and Norway. The majority of NMS13 migrants come to EU15 and EFTA countries for employment reasons. It has to be emphasized that mobile EU workers are a very specific group of migrants as not only they have unrestricted legal access to EU labour markets (after transition measures have run out) but additionally a number of EU regulations and directives as well as court rulings support their working conditions and social rights.

Using the special European Labour Force Survey (EU-LFS) module on immigrants and their descendants for 2014 this paper looks into the role of social networks as job finding strategy on the qualitative employment outcomes of recent NMS13 immigrants to Western Europe. Results are presented broken down for Continental, Mediterranean, Nordic and Anglo Saxon (UK) destination countries. Due to data restrictions, it is not possible to distinguish between different country of origin clusters. A clear advantage of the special module is that it allows to look at social networks and employment outcomes across a number of European countries - most available studies have so far looked at single countries only or adopted qualitative approaches. As many of the recent EU migrant workers are young we look separately at recent young and adult EU migrant workers.

To frame our paper, we use a combination of migration network and dual labour market theories. Social networks which are often co-ethnic networks are likely to increase the access to employment of migrant workers as they can facilitate information about available jobs and direct access to employers. We cannot test for this with our data though. If we follow the literature on immigrant niche occupations, regarding qualitative employment outcomes - here captured by subjective over-qualification and wages -, social networks are likely to have a negative impact (see e.g. Joassart-Marcelli 2014) particularly in a setting with comparatively high qualified migrant workers as is the case with post-enlargement intra-EU migration.

Indeed, our descriptive findings seem to give some indication of immigrant occupation or sectoral niches contributing to segmentation: In spite of similar skills levels as their peers young recent NMS 13 migrants more often work in manufacturing or the hospitality industry but less often work in the wholesale industry or in the public, educational or health sector compared to young nationals. They have much higher employment rates (except for the Continental destination country cluster) and work more hours per week.

Our analysis shows that in all European country clusters recent NMS13 migrants (and particularly those with low education levels) more often found their current job through social networks than nationals did; this strategy was more pronounced for adults than for youth. In a setting with partial or deficient information on destination country labour market opportunities and additional language challenges, looking for jobs via social networks might indeed be an obvious choice. At the same time our findings show for the most part that when recent NMS13 migrants found their jobs through social networks it is more likely that they are over-qualified for the position and that they fall in a lower earnings class as compared to recent migrants who used other job search methods. In particular, young recent migrants are affected rather often by over-qualification and most of them have rather low earnings. Thus using established social networks for job search might go hand in hand with sub-optimal qualitative employment outcomes. Immigrant occupational and sectoral niches are one factor here. However, the results 
differ between different welfare regimes and across individual and job characteristics of the NMS13 migrants.

Differences in outcomes across welfare regimes call for scrutinizing the role of labour demand (employers depending on migrant workers due to bottlenecks might be granting comparatively better working conditions), labour market regulation (high trade union density and collective bargaining coverage is likely to make it more difficult to offer sub-standard working conditions) and welfare institutions. Given that we do not have high enough case numbers and already have to cluster destination countries, using the EU-LFS data to test this quantitatively by way of multilevel models will not be possible. This calls for further country-by-country qualitative studies based on in-depth interviews which would then also be able to take into account differences by country of origin as have been pointed to among others by Kacmarczyk and Tyrowicz (2015).

The complex interaction between demographic, human capital (education level and, importantly, language skills) and job characteristics at the individual level calls for multivariate models which could test the role of social networks net of these other effects. In such models one could also test more specifically for the length of stay.

\section{Appendix}

Table 3: Weighted sample size(s) for specific NMS13 migrant groups in selected EU15(+2) countries

\begin{tabular}{|c|c|c|c|c|}
\hline & & $\begin{array}{c}\text { Nationals/ } \\
\text { natives of own } \\
\text { country }\end{array}$ & NMS13 & $\begin{array}{c}\text { Recent } \\
\text { (1-5 years) } \\
\text { NMS13 } \\
\end{array}$ \\
\hline \multirow{6}{*}{ Continental countries } & AT Austria & 4879 & 231 & 84 \\
\hline & BE Belgium & 10013 & 167 & 96 \\
\hline & CH Switzerland & 4018 & 84 & 30 \\
\hline & FR France & 37155 & 78 & 14 \\
\hline & LU Luxembourg & 294 & 12 & 4 \\
\hline & All - Continental & 56359 & 572 & 228 \\
\hline \multirow{5}{*}{ Mediterranean countries } & ES Spain & 41729 & 863 & 46 \\
\hline & GR Greece & 10180 & 105 & 16 \\
\hline & IT Italy & 55589 & 1277 & 155 \\
\hline & PT Portugal & 10168 & 24 & 3 \\
\hline & All - Mediterranean & 117666 & 2269 & 220 \\
\hline \multirow{4}{*}{ Nordic countries } & FI Finland & 5319 & 37 & 5 \\
\hline & NO Norway & 2990 & 121 & 72 \\
\hline & SE Sweden & 5740 & 52 & 22 \\
\hline & All - Nordic & 14049 & 210 & 99 \\
\hline \multirow{2}{*}{ Anglo-Saxon countries (UK) } & UK United Kingdom & 58330 & 1617 & 650 \\
\hline & All - Anglo-Saxon & 58330 & 1617 & 650 \\
\hline & All countries & 246404 & 4668 & 1197 \\
\hline
\end{tabular}

Source: Ad hoc module "Labour market situation of migrants and their immediate descendants (2014)" - European Labour Force Survey (EU-LFS). 
Table 4: NACE code for industries

\begin{tabular}{|c|c|}
\hline Industry & NACE code(s) \\
\hline Agriculture, forestry and fishing & A Agriculture, forestry and fishing \\
\hline Mining, energy and water & $\begin{array}{l}\text { B Mining and quarrying } \\
\text { D Electricity, gas, steam and air conditioning supply } \\
\text { E Water supply; sewerage, waste management and } \\
\text { remediation activities }\end{array}$ \\
\hline Manufacturing & C Manufacturing \\
\hline Construction & F Construction \\
\hline Wholesale and retail trade & $\begin{array}{l}\text { G Wholesale and retail; repair of motor vehicles and } \\
\text { motorcycles }\end{array}$ \\
\hline Gastronomy and accommodation & I Accommodation and food service \\
\hline Transport and communication & $\begin{array}{l}\text { H Transport and storage } \\
\mathrm{J} \text { Information and communication }\end{array}$ \\
\hline $\begin{array}{l}\text { Financial, professional, or } \\
\text { administrative services }\end{array}$ & $\begin{array}{l}\text { K Financial and insurance activities } \\
\text { L Real estate activities } \\
\text { M Professional, scientific and technical activities } \\
\text { N Administrative and support service activities }\end{array}$ \\
\hline $\begin{array}{l}\text { Public administration, education } \\
\text { and health }\end{array}$ & $\begin{array}{l}\text { O Public administration and defence; compulsory social security } \\
\text { P Education } \\
\text { Q Human health and social work activities }\end{array}$ \\
\hline Other services & $\begin{array}{l}\text { R Arts, entertainment and recreation } \\
S \text { Other service activities } \\
\text { T Activities of households as employers; undifferentiated goods- } \\
\text { and services-producing activities of household for own use }\end{array}$ \\
\hline (Not included in the analyses) & U Activities of extraterritorial organisations and bodies \\
\hline
\end{tabular}

\section{Bibliography}

Aguilera, M. B., and Massey, D. S. (2003). Social capital and the wages of Mexican migrants: New hypotheses and tests. Social Forces, 82(2): 671-701.

Arango, J. (2000). Explaining migration: a critical view. International Social Science Journal, 52(165): 283-296.

Arts, W. and Gelissen J. (2002). Three Worlds of Welfare Capitalism or More? A State of the Art Report, Journal of European Social Policy 12(2):137-158.

Castles, S. (2000). International Migration at the Beginning of the Twenty- First Century: Global Trends and Issues. International Social Science Journal, 52(165): 269-281.

Eade, J., Drinkwater, S. and Garapich, M. (2007) Class and Ethnicity: Polish Migrants in London, Research Report for the RES-000-22-1294 ESRC Project. University of Surrey.

European Integration Consortium (2009). Labour mobility within the EU in the context of enlargement and the functioning of the transitional arrangements. Available at http://doku.iab.de/grauepap/2009/LM_finalreport.pdf

European Parliament (2015). Labour market shortages in the European Union. Study for the EMPL 
committee, IP/A/EMP/ST/2013-06. Available at http://www.europarl.europa.eu/RegData/etudes/STUD/2015/542202/IPOL_STU(2015)54220 2_EN.pdf

Esping-Andersen, G. (1990). The three worlds of welfare capitalism. Princeton, NJ: Princeton University Press.

Ferrera, M. (1996). The "Southern" Model of Welfare in Social Europe. Journal of European Social Policy 6(1): 17-37.

Friberg, J. and Eldring, L. (2013). Labour migrants from Central and Eastern Europe in the Nordic countries: Patterns of migration, working conditions and recruitment practices. Nordic Council of Ministers.

Friberg, J. H., Arnholtz, J., Eldring, L., Hansen, N. W. and Thorarins, F. (2014). Nordic labour market institutions and new migrant workers: Polish migrants in Oslo, Copenhagen and Reykjavik. European Journal of Industrial Relations, 20(1): 37-53.

Gavanas. A. (2013). Migrant domestic workers, social network strategies and informal markets for domestic services in Sweden. Women's Studies International Forum, 36: 54-64.

Hyggen, C., Ortlieb, R., Sandlie, H.C. and Weiss, S. (2016). East-West and North-North Migrating Youth and the Role of Labour Market Intermediaries. The Case of Austria and Norway. STYLE Working Papers, WP6.2. CROME. University of Brighton, Brighton. http://www.style-research.eu/publications/working-papers

Janicka, A. and Kaczmarczyk, P. (2016). Mobilities in the crisis and post-crisis times: migration strategies of Poles on the EU labour market. Journal of Ethnic and Migration Studies, 42(10): 1693-1710.

Joassart-Marcelli, P. (2014). Gender, social network geographies, and low-wage employment among recent Mexican immigrants in Los Angeles. Urban Geography, 35(6): 822-851.

Kahanec, M. and Zimmermann, K. (2016). Labor Migration, EU Enlargement, and the Great Recession. Springer Berlin Heidelberg (chapter 1).

Kaczmarczyk, P., \& Tyrowicz, J. (2015). Winners and Losers among Skilled Migrants: The Case of Post-Accession Polish Migrants to the UK. IZA DP No. 9057.

Kalter, F. (2011). Social Capital and the Dynamics of Temporary Labour Migration from Poland to Germany. European Sociological Review, 27(5): 555-569.

Knight, J. (2015). Migrant Employment in the Ethnic Economy: Why do some migrants become ethnic entrepreneurs and others co-ethnic workers? Journal of International Migration and Integration, 16(3): 575-592.

Krissman, F. (2005). Sin Coyote Ni Patrón: Why the „Migrant Network“ fails to explain international migration. International Migration Review, 39(1): 4-44.

Kurekova, L. (2013). Welfare Systems as Emigration Factor: Evidence from the New Accession States. Journal of Common Market Studies, 51(4): 721-739.

Massey, D.S., Arango, J., Hugo, G., Kouaouci, A., Pellegrino, A. and Taylor, J.E. (1993). Theories of international migration. A review and appraisal. Population and Development Review, 19(3): 431-466. 
Mau, S. and Verwiebe, R. (2010). European societies: Mapping structure and change, Policy Press.

McCollum, D. and Findlay, A. (2015). 'Flexible' workers for 'flexible' jobs? The labour market function of A8 migrant labour in the UK. Work, Employment and Society, 29(3): 427-443.

Napierała J. and Fiałkowska K. (2013). Mapping the market for employment agencies in Poland, in: Friberg, J. \& Eldring, L. (eds.) Labour migrants from Central and Eastern Europe in the Nordic countries: Patterns of migration, working conditions and recruitment practices, Nordic Council of Ministers (chapter 11).

Peck, J. (1996). Structuring the labor market. A segmentation approach, in Peck, J. (Ed.) Work-Place. The Social Regulation of Labor Markets. Guilford Press New York/London: 46-80.

Pellizzari, M. (2010). Do friends and relatives really help in getting a good job? Industrial and Labor Relations Review, 63(3): 494-510.

Piore, M. J. (1979). Birds of Passage: Migrant labor in industrial societies. Cambridge: Cambridge University Press.

Rienzo, C. (2013). Migrants in the UK Labour Market: An Overview. Migration Observatory briefing. Oxford: COMPAS, University of Oxford.

Ryan, L. (2011). Transnational Relations: Family Migration among Recent Polish Migrants in London. International Migration, 49(2): 80-103.

Rubery, J. (2007). Developing segmentation theory: a thirty years perspective. Économies et Sociétés, 28(6): 941-964.

Samaluk, B. (2016). Migrant workers' engagement with labour market intermediaries in Europe: Symbolic power guiding transnational exchange. Work, Employment and Society, 30(3): 455471.

Spreckelsen, T., Leschke, J. and Seeleib-Kaiser, M. (2016). Labour market integration of young EU migrant citizens in Germany and the UK, STYLE Working Paper 6.4a, CROME. University of Brighton, Brighton. http://www.style-research.eu/publications/working-papers/

Stark, O. and Bloom, D. (1985). The New Economics of Labor Migration. The American Economic Review, 75(2), Papers and Proceedings of the Ninety-Seventh Annual Meeting of the American Economic Association: 173-178.

Vasta, E. (2004). Informal Employment and Immigrant Networks: A Review Paper. Centre on Migration, Policy and Society, Working Paper 04-02, University of Oxford.

Verhaeghe, P., Van der Bracht, K. and Van de Putte, B. (2015). Inequalities in social capital and their longitudinal effects on the labour market entry, Social Networks 40: 174-184

Verwiebe, R., Reinprecht, C., Haindorfer, R., and Wiesböck, L. (2015). How to Succeed in a Transnational Labor Market: Job Search and Wages among Hungarian, Slovak, and Czech Commuters in Austria. International Migration Review, online first:

DOI:10.1111/imre.12193 